\title{
PEMBELAJARAN SISTEM KOLOID MELALUI MEDIA ANIMASI UNTUK MENINGKATKAN AKTIVITAS DAN HASIL BELAJAR SISWA
}

\author{
Rohaeni Nur Eli ${ }^{1}$ dan Sari ${ }^{2}$ \\ ${ }^{1}$ SMK Negeri 2 Cimahi, Jalan Kamarung Km. 1,5 No 69 Citeureup Cimahi Utara, Kota \\ Cimahi, 40512, Indonesia \\ ${ }^{2}$ Program Studi Pendidikan Kimia, Jurusan Pendidikan MIPA, Fakultas Tarbiyah dan \\ Keguruan, Universitas Islam Negeri Sunan Gunung Djati Bandung, Jl. A. H. Nasution No. \\ 105, Bandung, 40614, Indonesia \\ ${ }^{1}$ E-mail: r.nureli@yahoo.com
}

\begin{abstract}
ABSTRAK
Telah dilakukan penelitian yang bertujuan untuk menganalisis peningkatan hasil belajar siswa pada konsep sistem koloid dalam pembelajaran melalui media animasi. Penelitian ini merupakan jenis penelitian tindakan kelas yang ditempuh dalam dua siklus. Setiap siklus terdiri dari empat tahap yaitu tahap perencanaan, pelaksanaan, pengamatan, dan refleksi. Subjek penelitian adalah 33 orang siswa SMKN 2 Cimahi kelas XI Teknik Kimia Industri. Teknik pengumpulan data menggunakan tes tertulis, angket dan observasi. Berdasarkan analisis data, pada siklus I diperoleh ketuntasan belajar 77,22 \% (nilai rata-rata 68,97), sedangkan pada siklus II diperoleh ketuntasan belajar $84,85 \%$ (nilai rata-rata 74,18 ). Aktivitas siswa dalam pembelajaran menunjukkan peningkatan yang positif, karena perilaku yang tidak diharapkan di kelas semakin berkurang, sedangkan perilaku positif semakin meningkat. Dengan demikian dapat disimpulkan bahwa penggunaan animasi dapat meningkatkan hasil belajar kimia siswa pada materi koloid.
\end{abstract}

Kata kunci: pembelajaran kimia, penelitian tindakan kelas, media animasi, sistem koloid.

\begin{abstract}
Research has been conducted which aims to analyze the improvement of student learning outcomes in the concept of colloidal systems in learning through animation media. This research is a type of classroom action research taken in two cycles. Each cycle consists of four stages, namely the stages of planning, implementation, observation, and reflection. The research subjects were 33 students of Cimahi Vocational High School 2 grade XI Industrial Chemical Engineering. Data collection techniques use written tests, questionnaires and observations. Based on data analysis, in the first cycle obtained learning completeness $77.22 \%$ (mean score 68.97), while in the second cycle learning completeness was obtained $84.85 \%$ (mean score 74.18). Student activity in learning shows a positive increase, because behavior that is not expected in the classroom decreases, while positive behavior increases. Thus it can be concluded that the use of animation can improve student chemistry learning outcomes in colloidal material.
\end{abstract}

Keywords: chemical learning, classroom action research, animation media, colloidal systems.

DOI: https://doi.org/10.15575/jtk.v3i2.3713 


\section{PENDAHULUAN}

Dalam memasuki era perkembangan ilmu pengetahuan dan teknologi dewasa ini harus diikuti dengan perkembangan kualitas manusia (Sudarsana, 2016). Hal tersebut selaras dengan tujuan Kurikulum 2013, yaitu untuk mempersiapkan manusia Indonesia agar memiliki kemampuan hidup sebagai pribadi dan warga negara yang beriman, produktif, kreatif, inovatif, dan afektif serta mampu berkontribusi pada kehidupan bermasyarakat, berbangsa, bernegara, dan peradaban dunia.

Dalam Pelaksanaan kurikulukum 2013 mengacu pada Permendikbud No. 64 Tahun 2013 tentang Standar Isi, sangat diharapkan siswa lebih aktif dalam mengikuti proses pembelajaran. Guru berperan sebagai fasilitator yang membimbing dan mengarahkan siswa agar terlibat aktif dalam pembelajaran. Keterlibatan aktif siswa dalam pembelajaran tersebut berkaitan dengan aktivitas penemuan dan pengembangan fakta, konsep dan prinsip ilmu pengetahuan (Burhanudin dkk., 2018).

Berdasarkan studi pendahuluan, SMK Negeri 2 Cimahi sudah menerapkan kurikulum 2013. Namun guru kimia merasa masih belum dapat melaksanakan pembelajaran kimia yang dapat mengembangkan aktivitas belajar dan kemampuan siswa secara optimal. Berdasarkan hasil observasi, proses pembelajaran kimia sudah dilaksanakan cukup baik, dengan memberikan kesempatan pada siswa belajar secara mandiri (student centered), antara lain sudah mencoba menerapkan pembelajaran berbasis masalah, tetapi siswa belum sepenuhnya belajar secara aktif, dan efektif. Siswa masih terlihat pasif pada beberapa kegiatan pembelajaran seperti diskusi dengan tanya jawab dengan guru.
Pelaksanaan yang tidak maksimal dapat terlihat dari hasil belajar siswa. Diketahui bahwa 21 siswa dari 38 siswa di kelas XI Teknik Kimia Industri A mendapatkan nilai di bawah KKM (Kriteria Ketuntasan Minimal) yaitu $\geq 75$ pada hasil belajar ranah kognitif. Berdasarkan temuan tersebut, dapat dikatakan bahwa hasil belajar kimia siswa di kelas tersebut rendah.

Salah satu materi kimia yang capaian hasil belajarnya rendah adalah konsep sistem koloid. Berdasarkan kurikulum, materi ini dipelajari di kelas XI Teknik Kimia Industri A dengan Kompetensi Dasar 3.15 yaitu menganalisis peran koloid dalam kehidupan berdasarkan sifat-sifatnya (kognitif) dan Kompetensi Dasar 4.15 yaitu mengajukan gagasan untuk memodifikasi pembuatan koloid berdasarkan pengalaman membuat beberapa jenis koloid (keterampilan). Materi sistem koloid erat kaitannya dengan kehidupan sehari-hari, sehingga materi ini sangat penting untuk dipelajari dan dipahami. Namun dalam pembelajaran siswa cenderung hanya menghapal tanpa memahami materi tersebut secara mendalam, sehingga tuntutan kompetensi dasar berdasarkan kurikulum tidak tercapai. Di samping itu ada kecenderungan dalam pembelajaran siswa kurang antusias dan merasa bosan.

Oleh karena, itu diperlukan perbaikan pembelajaran agar siswa mencapai hasil belajar yang lebih baik. Berbagai hasil penelitian telah menyarankan pentingnya suatu alat bantu yang mencakup sistem verbal dan gambar berbasis pada teori dual coding multimedia agar dapat memvisualisasikan konsep-konsep yang sukar dimengerti siswa (Yuliani dkk., 2017). Penggunaan media pembelajaran berupa animasi atau multimedia dapat membuat 
kondisi pembelajaran kimia menjadi lebih menarik dan materi yang disampaikan guru mudah dipahami siswa (Haryati dkk., 2013). Umar (2013) juga menyatakan bahwa penggunaan media pembelajaran dapat membuat kondisi pembelajaran lebih efektif sehingga dapat meningkatkan hasil belajar siswa. Salah satu media yang dipilih agar dapat mengkonkritkan konsep kimia yang abstrak yaitu media animasi. Hasil penelitian Meirina (2013) menyimpulkan bahwa media animasi pembelajaran dapat mempermudah guru dalam menyampaikan konsep, menambah motivasi, pembelajaran menjadi lebih menarik, menyenangkan, meningkatkan rasa ingin tahu dan dapat mempermudah siswa dalam memahami materi pergeseran kesetimbangan kimia. Hal ini juga diperkuat oleh penelitian Sari (2014) mengenai pengaruh media animasi terhadap hasil belajar IPA, siswa slow learner menunjukan bahwa setelah menggunakan media animasi didapatkan hasil rata-rata akhir postes berada pada kategori baik, adanya peningkatan hasil belajar.

Penelitian lain yang mendukung pentingnya penggunaan media animasi dalam pembelajaran adalah hasil penelitian Sakti dkk. (2012) yang menunjukkan terdapat pengaruh signifikan model pembelajaran langsung (Direct Instruction) melalui media animasi terhadap minat belajar dan pemahaman konsep. Penggunaan multimedia berbasis saintifik pada konsep sistem periodik mempermudah proses pembelajaran di kelas (Sari dkk., 2017).

Berdasarkan pemikiran tersebut, dilakukan penelitian tindakan kelas untuk memperbaiki hasil belajar siswa. Pada studi ini dilaporkan hasil penelitian yang mencakup deskripsi aktivitas siswa dalam pembelajaran kimia dan hasil belajar siswa pada setiap siklus setelah pembelajaran menggunakan media animasi pada materi sistem koloid.

\section{METODE PENELITIAN}

Penelitian ini dilaksanakan dengan menggunakan metode penelitian tindakan kelas. Penelitian tindakan (Action research) adalah penelitian yang dilakukan untuk mencari sesuatu dasar pengetahuan praktis dalam rangka memperbaiki keadaan atau situasi yang dilakukan secara terbatas (Wiersma, 2009). Penelitian tindakan kelas dilakukan pada situasi yang sedang berlangsung, dengan tahapan pelaksanaan dua siklus dengan masing-masing siklus 2 kali pertemuan. Hasil tes tiap siklus dianalisis untuk mengetahui sejauh mana peningkatan aktivitas dan hasil belajar siswa pada konsep sistem koloid.

Data penelitian diperoleh dari siswa kelas XI Teknik Kimia Indusri A berjumlah 33 orang, yang terdiri dari 23 orang laki-laki dan 10 orang perempuan. Data-data yang diperoleh adalah merupakan gambaran umum tentang proses pembelajaran pada mata pelajaran Kimia di kelas XI Teknik Kimia Indusri A. Alur penelitian terdapat pada Gambar 1.

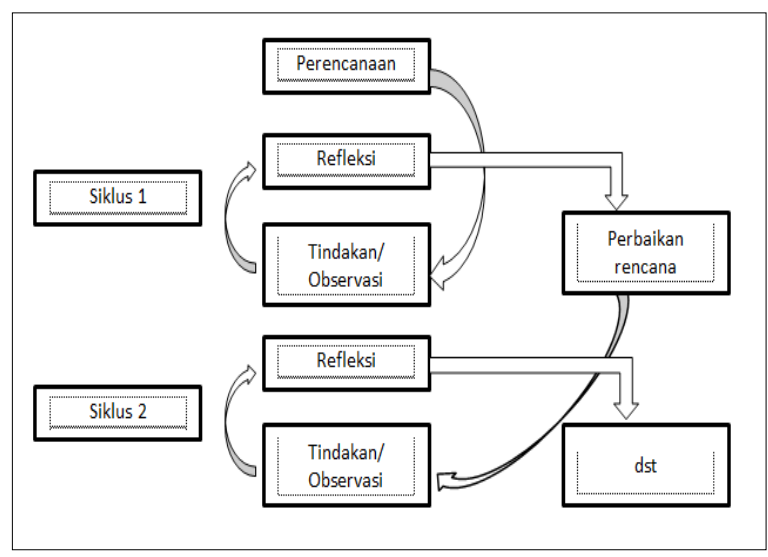

Gambar 1. Bagan Rancangan Pelaksanaan PTK Model Spiral (Arikunto, 2006) 
Berdasarkan alur penelitian, instrumen penelitian yang digunakan dalam penelitian ini dikelompokkan menjadi instrumen untuk tahap persiapan, pelaksanaan, dan evaluasi hasil pembelajaran. Instrumen pada tahap pelaksanaan adalah berupa rencana pelaksanaan pembelajaran (RPP). RPP ini digunakan sebagai petunjuk guru dalam kegiatan proses pembelajaran untuk mencapai tujuan pengajaran yang dilaksanakan dalam satu pokok bahasan.

Media pembelajaran yang digunakan berupa animasi kimia untuk sistem koloid. Pada siklus I digunakan animasi untuk menggambarkan jenis-jenis koloid dan sifat-sifat koloid. Sedangkan pada siklus II diimplementasikan animasi kimia yang menggambarkan pembuatan koloid.

Langkah-langkah pembelajaran mengacu pada pendekatan saintifik yang meliputi tahap mengamati, menanya, mengumpulkan data, mengasosiasi, dan mengkomunikasikan. Pengambilan data diperoleh dari LKS yang digunakan oleh peserta didik pada saat pembelajaran berlangsung dan Lembar Observasi yang digunakan oleh observer pada saat pembelajaran berlangsung. Pembelajaran dilaksanakan dalam dua siklus. Tiap siklus dilaksanakan dalam dua kali pertemuan. Alokasi waktu tiap pertemuan adalah $4 \times 45$ menit.

Tahap evaluasi dilakukan menggunakan instrumen tes tertulis (tes awal dan tes akhir). Hasil tes pada siklus I dan siklus II diolah dengan langkah-langkah sebagai berikut :
a) Mengubah skor menjadi nilai
b) Membuat tabel ketuntasan individu (daya serap). Kriteria Nilai Akhir (NA) $\geq 75$, siswa dianggap tuntas/skor total siswa $\geq$ 75 .
c) Menghitung ketuntasan kelas.

\begin{abstract}
Ketuntasan $=\frac{\text { Jumlah skor } \geq 75}{\text { Jumlah Siswa }} \times 100 \%$
Kriteria Ketuntasan Kelas $\geq 85 \%$, kelas dianggap tuntas

d) Data yang didapat dari hasil observasi diolah menjadi persentase untuk menunjukkan persen jumlah kemunculan aktivitas yang diharapkan.
\end{abstract}

\section{HASIL DAN PEMBAHASAN}

Dalam penelitian ini telah dilakukan pengembangan beberapa aspek, antara lain; (1) animasi, di mana pembelajaran dibantu dengan animasi-animasi mengenai jenis-jenis koloid dan sifat-sifat koloid. Pemanfaataan media animasi ditujukan untuk menggambarkan materi yang sebelumnya abstrak menjadi sesuatu yang dapat diamati, baik dalam bentuk analogi maupun penggambaran. Adanya stimulus dengan lebih dari satu jenis dalam media animasi menyebabkan materi dapat dipahami dengan lebih cepat sebagaimana dinyatakan Fitri (2016). (2) Teknik evaluasi, yang dilakukan pada setiap akhir siklus tindakan untuk mengkaji pencapaian belajar peserta didik dan sebagai acuan dalam pelaksanaan perbaikan pada siklus berikutnya.

Materi pembelajaran pada siklus I adalah jenis-jenis koloid dan sifat-sifat koloid. Materi pembelajaran pada siklus II adalah pembuatan koloid. Proses pembelajaran berlangsung sebagaimana siklus I dengan perbaikan beberapa teknik pembelajaran sesuai hasil refleksi pada siklus I. Pada pembelajaran ini digunakan beberapa animasi yang menggambarkan bagaimana pembuatan koloid. Desain yang atraktif dan tidak dimiliki oleh sebagian besar media yang lain merupakan kelebihan utama dari media animasi, sehingga mengajak siswa untuk berinteraksi langsung dengan materi pembelajaran. 
Pada Tabel 1 disajikan hasil pengamatan aktivitas siswa dalam pembelajaran untuk setiap siklus. Berdasarkan Tabel 1, pada siklus pertama, 20 orang peserta didik (60,60\%) melakukan pengamatan pada animasi/virtual lab yang disajikan guru.
15 orang $(45,45 \%)$ terlihat sangat aktif mengumpulkan informasi $(84,85 \%)$ dan terlihat bersemangat dalam mengolah data hasil pengumpulan informasi, 30 orang $(90,91 \%)$ sangat komunikatif dalam mempresentasikan hasil temuannya.

Tabel 1. Tabel Hasil Pengamatan Aktivitas Siswa dalam Pembelajaran dengan berbantukan Animasi

\begin{tabular}{|c|l|c|c|c|c|}
\hline \multirow{2}{*}{ No. } & \multicolumn{1}{|c|}{ Komponen yang diamati } & \multicolumn{4}{|c|}{ Siklus } \\
\cline { 3 - 6 } & \multicolumn{2}{|c|}{ I } & \multicolumn{2}{|c|}{ II } \\
\cline { 3 - 6 } & $\begin{array}{l}\text { Mumlah } \\
\text { disajikan guru. }\end{array}$ & 20 & 60,60 & 33 & 100 \\
\hline 2. & $\begin{array}{l}\text { Membuat pertanyaan-pertanyaan dari } \\
\text { yang diamati dan mencoba membuat } \\
\text { jawaban sementara. }\end{array}$ & 15 & 45,45 & 25 & 75,75 \\
\hline 3. & $\begin{array}{l}\text { Aktif dalam mengumpulkan informasi } \\
\text { untuk memecahkan masalah }\end{array}$ & 24 & 72,72 & 22 & 81,81 \\
\hline 4. & $\begin{array}{l}\text { Semangat mengumpulkan mengolah } \\
\text { data hasil informasi }\end{array}$ & 28 & 84,85 & 30 & 90,91 \\
\hline 5. & $\begin{array}{l}\text { Komunikatif dalam mempresentasikan } \\
\text { hasil pemecahan masalah. }\end{array}$ & 30 & 90,91 & 31 & 93,94 \\
\hline
\end{tabular}

Hasil analisis terhadap masing-masing aktivitas siswa dalam pembelajaran pada siklus I belum menunjukkan hasil yang memuaskan, karena masih terdapat siswa yang mempunyai nilai dibawah 75 yaitu sekitar 31,02 \%. Hal ini antara lain disebabkan peserta didik belum terbiasa belajar melalui metode pembelajaran dengan bantuan animasi yang di mana dalam proses pembelajaran terlihat banyak peserta didik yang bingung bagaimana mengamati, apa yang harus diamati, dan bagaimana menuangkan hasil pengamatan terkait materi sistem koloid dan mendiskusikan hasilnya.

Pada siklus II, berdasarkan Tabel 1 diperoleh informasi bahwa semua siswa (100\%) melakukan pengamatan animasi/virtual lab yang disajikan guru, $75,75 \%$ siswa dapat membuat pertanyaan-pertanyaan dari yang diamati dan mencoba membuat jawaban sementara, hampir semua siswa terlihat sangat aktif mengumpulkan informasi dan bersemangat dalam mengolah data hasil pengumpulan informasi sangat komunikatif dalam mempresentasikan hasil temuannya. Analisis terhadap masing-masing aktivitas peserta didik dalam pembelajaran cukup menunjukkan hasil yang memuaskan, karena berada di atas $50 \%$ peserta didik dari tiga kali pertemuan pembelajaran dengan pembelajaran berbantukan animasi. Hal ini antara lain disebabkan peserta didik sudah mulai terbiasa belajar melalui metode pembelajaran berbantukan animasi di mana dalam proses pembelajaran terlihat banyak peserta didik yang sudah dapat mencoba memecahkan permasalahan terkait sistem koloid dan mendiskusikan hasilnya. 
Pada Tabel 2 disajikan data pengamatan siswa yang off task dalam setiap siklus. Pada siklus I siswa masih menunjukkan tingkah laku yang tidak diinginkan. Namun demikian perilaku tersebut mengalami penurunan pada siklus II.

Tabel 2. Tabel Data Pengamatan Aktivitas Siswa yang Off Task pada Setiap Siklus

\begin{tabular}{|l|l|c|c|c|c|}
\hline \multirow{2}{*}{ No. } & \multicolumn{2}{|c|}{ Komponen yang diamati } & \multicolumn{4}{|c|}{ Siklus } \\
\cline { 3 - 6 } & & \multicolumn{2}{|c|}{ I } & \multicolumn{2}{|c|}{ II } \\
\cline { 3 - 6 } 1. & Berbincang & 7 & 21,21 & 2 & 6,06 \\
\hline 2. & Menganggu teman & 5 & 15,15 & 2 & 6,06 \\
\hline 3. & Keluar masuk kelas & 4 & 12,12 & 2 & 6,06 \\
\hline 4. & Mengantuk & 2 & 6,06 & 1 & 3,03 \\
\hline 5. & Suka main-main & 8 & 24,24 & 2 & 6,06 \\
\hline
\end{tabular}

Peningkatan hasil belajar siswa diketahui dari data tes awal dan tes akhir dengan jenis soal pilihan ganda sebanyak 25 soal.

Hasil tes awal memberikan gambaran sejauh mana kemampuan kognitif peserta didik sebelum diberikan pembelajaran dengan bantuan animasi memperlihatkan seluruh peserta didik memperoleh nilai di bawah KKM. Sedangkan hasil tes akhir gambaran sebanyak 23 orang dari 33 orang peserta didik memperoleh nilai $\geq 75$. Perbandingan hasil tes awal dan hasil tes akhir tergambarkan lebih jelas pada Gambar 2.

Gambar 2 memperlihatkan pada saat dilakukan tes awal pada peserta didik tidak ada satupun peserta didik yang mendapatkan nilai sesuai KKM yang ditetapkan sekolah, nilai tertinggi hanya pada angka 20 sedangkan nilai terendah pada angka 52 , hal ini dapat dimaklumi karena peserta didik belum mendapatkan pembelajaran dengan bantuan media animasi setelah proses pembelajaran pada siklus I selesai, selanjutnya pada akhir siklus dilakukan tes akhir (kognitif) untuk mengetahui kemampuan peserta didik dalam menyerap materi yang telah dibahas. Dari Tabel 1 terlihat peningkatan yang cukup signifikan pada hasil tes akhir di mana dari 33 peserta didik terdapat 24 orang $(72,22 \%)$ yang dapat menuntaskan pembelajaran nilai terendah berada pada 40 dan skor tertinggi pada angka 80.

Nilai rata-rata yang diperoleh peserta didik dari hasil tes formatif pada siklus I sebesar 68,97 hanya 24 peserta didik yang memenuhi kriteria ketuntasan belajar yang ditetapkan sekolah (nilai $\geq 75$ ). Bila dilihat dari ketuntasan belajar secara klasikal, hasil tindakan pada siklus I belum menunjukkan keberhasilan yang memuaskan karena masih dibawah $85 \%$. Nilai hasil belajar yang dicapai pada siklusl ini belum memenuhi indikator keberhasilan tindakan yang diinginkan (85\% peserta didik memperoleh nilai $\geq 75$ ).

Berdasarkan hasil observasi terhadap guru dan refleksi pada siklus I, diperoleh bahwa: (1) kegiatan pembelajaran masih didominasi oleh guru, guru tidak banyak memberikan kesempatan pada peserta didik untuk berfikir 
sendiri dalam menemukan konsep-konsep baru, (2) peserta didik masih terlihat kurang bersemangat dalam berdiskusi dan tanya jawab, karena pembelajaran dengan bantuan animasi peserta didik belum pernah dilaksanakan, (3) guru kurang memberikan waktu yang cukup kepada peserta didik untuk menjawab pertanyaan.

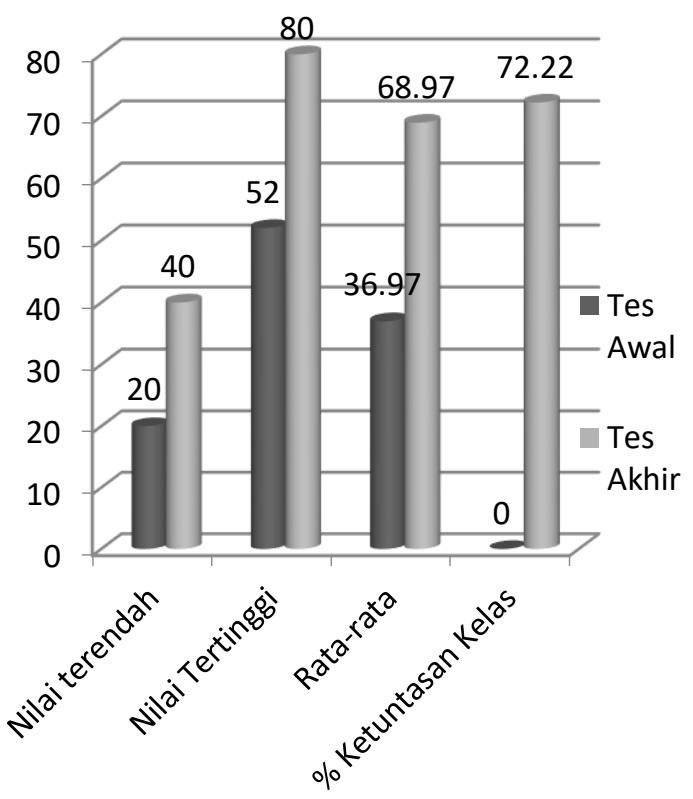

Gambar 2. Grafik Perbandingan Peningkatan
Hasil Belajar Peserta Didik pada
Siklus I

Namun yang terpenting dari kesemua analisis di atas adalah pembelajaran dengan bantuan animasi dapat meningkatkan hasil belajar peserta didik terbukti dengan rata-rata nilai tes awal 52 menjadi 84 pada tes akhir lebih dari setengahnya peserta didik mendapatkan nilai 75 setelah pembelajaran dengan berbantuan animasi. Hal tersebut disebabkan adanya pengaruh positif penggunaan media animasi terhadap pembelajaran kimia sebagaimana dinyatakan Fitriani (2014).

Berdasarkan refleksi terhadap aktivitas dan hasil belajar yang diperoleh pada siklus I, dipandang perlu adanya perbaikan dalam melaksanakan siklus II. Perbaikan yang dilakukan antara lain dengan lebih memotivasi dan menarik perhatian peserta didik pada materi yang sedang dibahas, terutama aspek-aspek yang masih belum optimal dilaksanakan.

Tes formatif dilakukan pada akhir siklus II untuk mengetahui kemampuan penguasaan materi siswa yang telah dibahas, jumlah siswa yang memenuhi kriteria ketuntasan belajar yang ditetapkan sekolah dengan nilai $\geq 75$ adalah 85.85 \% ketuntasan ini menunjukkan hasil yang memuaskan. Nilai hasil belajar yang dicapai pada siklus II apabila dibandingkan dengan nilai rata-rata hasil belajar yang dicapai siswa pada siklus I, mengalami peningkatan sebesar 13,36\%. Perbandingan hasil tes awal dan hasil tes akhir tergambarkan lebih jelas pada Gambar 3.

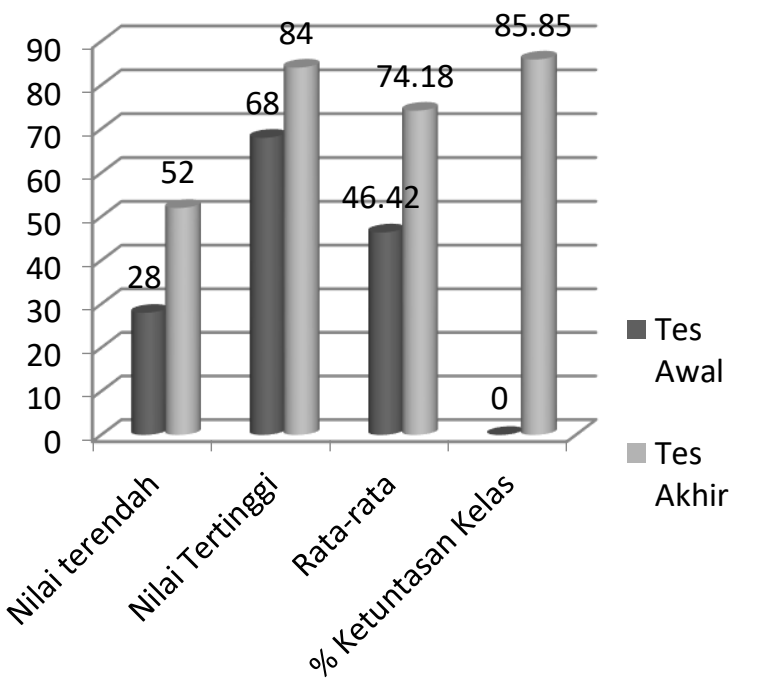

\section{Gambar 3. Grafik Perbandingan Peningkatan Hasil Belajar Peserta didik pada Siklus II}

Dari hasil yang diperoleh pada siklus II menunjukkan KKM sudah tercapai, bila ditinjau dari segi peningkatan hasil belajar dan aktivitas siswa dari siklus I ke siklus II. Hal ini antara lain disebabkan siswa telah terbiasa Jurnal Tadris Kimiya 3, 2 (Desember 2018): 135-144 
dengan pembelajaran berbantukan animasi sehingga dapat mempermudah dalam memahami konsep-konsep kimia pada materi sistem koloid dan guru dalam proses pembelajaran bertindak sebagai fasilitator.

Berdasarkan hasil observasi dan refleksi yang dilakukan oleh semua tim peneliti menyatakan bahwa pembelajaran pada siklus II sudah dapat mengatasi kelemahan pada siklus I, seperti: (1) guru sudah memberikan waktu yang cukup kepada siswa untuk menjawab pertanyaan, (2) guru sudah memberikan motivasi dan penguatan yang cukup pada siswa, (3) guru sudah maksimal membimbing siswa dalam menarik kesimpulan. Secara keseluruhan, dapat dikatakan bahwa pengembangan pembelajaran melalui penerapan pembelajaran berbantukan animasi dapat meningkatkan hasil belajar peserta didik baik dari siklus I ke siklus II.

\section{Pembelajaran system koloid dengan berbantukan animasi membuat proses pembelajaran menjadi menarik sehingga meningkatkan minat siswa dalam menyenangi pembelajaran yang dilaksanakan seperti yang diutarakan oleh Fitri (2016). Media pembelajaran berperan dalam mendorong keterlibatan aktivitas mental siswa dalam memahami, mengatur, dan mengakses informasi (Arsyad, 2011).}

Hasil penelitian ini, memperkuat pentingnya dalam proses pembelajaran memilih dengan tepat media yang cocok dan sesuai serta layak digunakan. Berbagai faktor yang mempengaruhi siswa terhadap penggunaan media diantaranya psikologi, kesiapan belajar, dan penguasaan anak. Oleh karena itu guru sebagai fasilitator perlu mempelajari bagaimana menetapkan media pembelajaran agar dapat mengefektifkan pencapaian tujuan pembelajaran dalam proses belajar mengajar (Prawiro, 2012). Dengan digunakannya media dalam proses pembelajaran maka materi kimia menjadi lebih menyenangkan dan mudah dimengerti oleh siswa.

\section{KESIMPULAN}

Penerapan pembelajaran dengan berbantukan animasi pada materi koloid dapat mengatasi kesulitan belajar siswa kelas XI Teknik Kimia Industri A, serta dapat meningkatkan hasil belajar siswa. Hal ini ditunjukkan dengan meningkatnya nilai ratarata kelas pada siklus I sebesar 68,97 dengan menunjukkan perolehan ketuntasan belajar $72,22 \%$, sedangkan nilai rata-rata kelas pada siklus II sebesar 74,18 dengan ketuntasan belajar $84,85 \%$. Tanggapan siswa terhadap penerapan pembelajaran dengan berbantukan animasi menunjukkan peningkatan yang positif, terlihat dari data hasil observasi dengan berkurangnya hal-hal yang tidak diinginkan di kelas serta terlihat dari keaktifan siswa di kelas. 


\section{DAFTAR PUSTAKA}

Arikunto, S. (2006). Dasar-dasar Evaluasi Pendidikan. Jakarta: Bumi aksara.

Arsyad, A. (2004). Media Pembelajaran. Jakarta: Raja Grafindo Persada.

Burhanudin, R. Subarkah, C, Z., \& Sari. (2018). Penerapan Model Pembelajaran Content Context Connection Researching Reasoning Reflecting (3C3R) Untuk Mengembangkan Keterampilan Generik Sains Siswa Pada Konsep Koloid. JTK: Jurnal Tadris Kimiya 3, 1 (Juni 2018): 186-196.

Fitri, H., \& Ismulyati, S. (2016). Kimia Peningkatan Hasil Belajar Siswa dengan Media Animasi pada Materi Koloid di Kelas XI IPA 3 SMAN 1 Unggul Darul Imarah aceh Besar. J. Edu.Kim., 1 (1) 1924.

Fitriani, A., Danial, M., \& Wijaya, M. (2014). Pengaruh Penggunaan Media Animasi pada Model Discovery Learning terhadap Hasil Belajar Kimia Peserta Didik Kelas X MIA SMAN 1 Bungoro (Studi pada Materi Pokok Ikatan Kimia). CHEMICA, 15(2), 114-122.

Haryati, S., \& Pratiwi, R. (2013). Pemanfaatan Media Animasi dalam Pembelajaran Kimia untuk Meningkatkan Motivasi dan Prestasi Belajar Siswa di SMAN 12 Pekanbaru. Prosiding SEMIRATA 2013, 1(1).

Meirina, A. M. (2013). Pengembangan Media Animasi Pembelajaran Berbasis Multipel Representasi pada Materi Faktor-faktor yang Mempengaruhi Pergeseran Kesetimbangan Kimia. Skripsi, Universitas Lampung. Bandar Lampung.
Prawiro, S. A., \& Irawan, A. H. (2012). Perancangan Media Pembelajaran Interaktif Ilmu Pengetahuan Alam untuk Siswa Kelas 4 SD dengan Metode Learning The Actual Object. J. Sains dan Seni ITS, vol. 1, no. 1, pp. 28-33.

Sakti, I., Yuniar Mega, P., \& Eko, R. (2012). Pengaruh Model Pembelajaran Langsung (Direct Instruction) melalui Media Animasi berbasis Macromedia Flash terhadap Minat Belajar dan Pemahaman Konsep Fisika Siswa di SMA Plus Negeri 7 Kota Bengkulu. EXACTA, 10(1), 1-10.

Sari, N. W., \& Samawi, A. (2014) Pengaruh Penggunan Media Animasi terhadap Hasil belajar IPA Siswa Slow Learner. P3LB. 1, (2) , 140-144.

Sari. S., Anjani. R., Farida. I., \& Ramdhani, M. A. (2017). Using Android-Based Educational Game for Learning Colloid Material. Journal of Physics: Conf. Series 895 (2017) 012012.

Sari. S., Aryana. D. M., Subarkah, C. Z., \& Ramdhani. M. A. (2017). Multimedia Based on Scientific Approach for Periodic System of Element. IOP Conf. Series: Materials Science and Engineering 288 (2017) 012137.

Sudarsana, I. K. (2016). Peningkatan Mutu Pendidikan Luar Sekolah dalam Upaya Pembangunan Sumber Daya Manusia. Jurnal Penjaminan Mutu, 1(1), 1-14.

Umar. (2013). Media Pendidikan: Peran dan Fungsinya dalam Pembelajaran. Jurnal Tarbawiyah. Vol. 10, No.2, 126-141. 

Animasi untuk Meningkatkan Aktivitas dan Hasil Belajar Siswa

Wiersma, W., \& Jurs, G.S. (2009). Research Methods in Education an Introduction. Boston: New York.

Yuliani, E., Windayani, N., \& Sari. (2017). Desain Multimedia berbasis Android berorientasi Keterampilan Berpikir Kritis pada Konsep Asam dan Basa. Prosiding Snips 2017. ISBN: 978-602-61045-2-6 378. 